\title{
Picroside II protects cardiomyocytes from hypoxia/ reoxygenation-induced apoptosis by activating the PI3K/Akt and CREB pathways
}

\author{
FAN-JI MENG, SU-MIN JIAO and BO YU \\ Department of Cardiology, The First Affiliated Hospital of China Medical University, Shenyang, P.R. China
}

Received February 15, 2012; Accepted April 9, 2012

DOI: $10.3892 / \mathrm{ijmm} .2012 .987$

\begin{abstract}
Picroside II, an iridoid glucoside found in the root of Picrorhiza scrophulariiflora Pennell (Scrophulariaceae), has been demonstrated to reduce apoptosis in neuronal cells and other cell types. However, whether picroside II has a protective effect against cardiomyocyte apoptosis is poorly understood. In the present study, we investigated the cardioprotective role of picroside II and the underlying mechanisms in hypoxia/reoxygenation-induced cardiomyocyte apoptosis. The pretreatment with picroside II markedly attenuated hypoxia/reoxygenationinduced cell damage dose-dependently, which was evident by the increased cell viability and the corresponding decrease in lactate dehydrogenase release (LDH). The pretreatment with picroside II inhibited apoptosis confirmed by Annexin V-FITC staining, Hoechst 33258 nuclear staining and by assessment of caspase- 3 activity. In addition, we found that picroside II not only increased the expression of Bcl-2, while decreasing Bax expression, but also augmented Akt and cAMP response element-binding protein (CREB) phosphorylation and ultimately inhibited hypoxia/reoxygenation-induced apoptosis. Furthermore, the protective effects of picroside II were abrogated by pretreatment of the cells with wortmannin or LY294002, a specific PI3K inhibitor. The present study suggests that picroside II inhibits hypoxia/reoxygenation-induced apoptosis in cardiomyocytes by activating the PI3K/Akt and CREB pathways and modulating expression of Bcl-2 and Bax.
\end{abstract}

\section{Introduction}

Apoptosis, a genetically programmed form of cell death, is a tightly regulated process to maintain tissue homeostasis and eliminate unwanted or dysfunctional cells in multicellular organ-

Correspondence to: Professor Bo Yu, Department of Cardiology, The First Affiliated Hospital of China Medical University, Liaoning, Shenyang 110001, P.R. China

E-mail: fanjimeng2060@yahoo.cn

Key words: picroside II, cardiomyocytes, apoptosis, Akt, cyclic AMP response element-binding protein, hypoxia/reoxygenation isms. The dysregulation of apoptosis can lead to a variety of heart diseases including heart failure and myocardial infarction with or without reperfusion injury $(1,2)$. The role of apoptosis in heart diseases is becoming increasingly clear. Therefore, it is vital to develop a potential therapeutic strategy to block or prevent inappropriate apoptosis in heart diseases.

Picroside II (h-D-glucopyranoside,1a,1b,2,5a,6,6a-hexahydro-6-[(4-hydroxy-3-methoxybenzoyl)oxy]-1a(hydroxymethyl) oxireno[4,5]cyclopenta[1,2-c]pyran-2-yl) is a major iridoid glucoside isolated from Picrorhiza scrophulariiflora Pennell (Scrophulariaceae) (Fig. 1) (3). Previous studies have shown that picroside II has a wide range of pharmacological effects, including neuroprotective $(4,5)$, hepatoprotective (6), antioxidation (7), anticholestatic, anti-inflammatory and immunemodulating activities $(8,9)$. In addition, picroside II is also reported to possess potential anti-apoptotic activities in hepatocytes (6), and rat model of focal cerebral ischemia (5). Therefore, it seems reasonable to investigate whether picroside II is able to protect cardiomyocytes against apotosis.

$\mathrm{Akt}$, a serine/threonine kinase, is the primary mediator of Phosphoinositide 3-kinase (PI3K)-initiated signaling. The PI3K/Akt pathway regulates the process of cell survival through phosphorylation of a variety of downstream targets such as the Bcl-2 family member Bad, caspase-9 and CREB (10). The pro- and anti-apoptotic members of the Bcl-2 family are intrinsic to the apoptotic pathway; $\mathrm{Bcl}-2$ and $\mathrm{Bcl}-\mathrm{xL}$ induce cell survival, whereas Bax and Bad promote cell death $(11,12)$. It is widely accepted that Bcl-2 family, located in the outer membranes of the mitochondria, can regulate mitochondrial outer membrane permeability and trigger apoptosis (13). The $\mathrm{Bcl}-2$ protein inhibits apoptosis by preventing the release of cytochrome $\mathrm{c}$ and the subsequent activation of caspases (14).

In the present study, we investigated the effect of picroside II on hypoxia/reoxygenation-induced apoptosis in cardiomyocytes and, most importantly, explored the possible underlying mechanisms.

\section{Materials and methods}

Animals. The animal use in this study was performed according to the Guide for the Care and Use of Laboratory Animals published by the National Institutes of Health (NIH publication no. 85-23, revised 1996). The use of animals was 


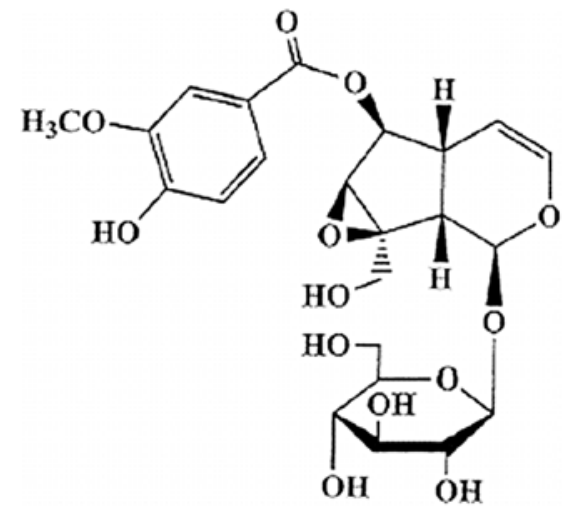

Figure 1. Chemical structure of picroside II.

also reviewed and approved by the China Medical University Animal Care Review Committee. Neonatal Sprague-Dawley 1to 3-day-old rats [Grade II, Certificate Number SCXK-(Liao) 2009-0001] were purchased from China Medical University (Shenyang, China).

Chemicals and reagents. Picroside II (purity >99\%), was purchased from the Chinese National Institute for the Control of Pharmaceutical and Biological products (Beijing, China). Dulbecco's modified Eagle's medium (DMEM), DMEM glucose-free, new-born calf serum and trypsin were purchased from Gibco-BRL (Carlsbad, CA, USA). Collagenase II was purchased from Invitrogen Life Technologies (Carlsbad, CA, USA). ECL reagent kit was purchased from Pierce Biotechnology, Inc. (Rockford, IL, USA). Antibodies against Akt, phospho-Akt (Ser-473), CREB and phospho-CREB, were obtained from Bioworld Technology, Inc. (Minneapolis, MN, USA). anti-Bcl-2 antibody, anti-Bax antibody and anti- $\beta$-actin antibody was purchased from Boster Bilogical Technology, Ltd. (Wuhan, China). The detection kits of lactate dehydrogenase (LDH), were purchased from the Nanjing Jiancheng Bioengineering Institute (Nanjing, China). bicinchoninic acid (BCA) protein assay kit, 2-(4-Morpholinyl)-8-phenyl1(4H)-benzopyran-4-one hydrochloride (LY294002) and wortmannin were supplied by Byeotime (Jianshu, China). Annexin V-FITC apoptosis detection kits were obtained from Nanjing KeyGen Biotech, Co, Ltd. (Nanjing, China). All other chemicals were purchased from Sigma-Aldrich. The purity of all reagents was at least analytical grade.

Primary culture of neonatal rat cardiomyocytes. The primary culture of neonatal rat cardiac ventricular myocytes was prepared from Sprague-Dawley rats (1- to 3-day-old) based on a previously published protocol with some modifications (15). Briefly, hearts were harvested and placed in ice-cold D-Hank's buffer. Ventricles were separated and cut into $1-\mathrm{mm}^{3}$ pieces. The tissue fragments were digested by treatment with $0.06 \%$ trypsin once $\left(37^{\circ} \mathrm{C}\right)$ and subsequently with $0.08 \%$ collagenase II $4-5$ times $\left(37^{\circ} \mathrm{C}\right)$. The cell suspension was then filtered and centrifuged for $8 \mathrm{~min}\left(120 \mathrm{x} \mathrm{g}, 4^{\circ} \mathrm{C}\right)$, and finally resuspended in Dulbecco's modifed Eagle's media supplemented with $10 \%$ fetal calf serum, penicillin $(100 \mathrm{U} / \mathrm{ml})$ and streptomycin $(100 \mathrm{U} / \mathrm{ml})$. Resuspended cells were plated onto 6-well plates in a humidified incubator $\left(5 \% \mathrm{CO}_{2}, 95 \%\right.$ air, $37^{\circ} \mathrm{C}$ ) for $2 \mathrm{~h}$ to exclude fibroblasts cells based on the fact that the fibroblasts cells attach to the surface more rapidly. To prevent proliferation of fibroblasts, $0.1 \mathrm{mmol} / 1$ 5-bromo2'-deoxyuridine (BrdU) was added to the culture medium. Non-adherent cells were then replated onto fresh 96- and 6 -well plates $\left(1.2 \times 10^{5}\right.$ and $2 \times 10^{6}$ cells/well, respectively) and incubated for 3-4 days before the experiment.

Hypoxia-reoxygenation model. In the present study, we used the model of hypoxia-reoxygenation in vitro which was similar to that described by Zhu et al (16). Briefly, before starting the experiments, the cultured cardiomyocytes were carefully washed 3 times with Hank's solution (5 mM HEPES, $137 \mathrm{mM}$ $\mathrm{NaCl}, 4 \mathrm{mM} \mathrm{KCl}, 1 \mathrm{mM} \mathrm{MgCl} 2,1.5 \mathrm{mM} \mathrm{CaCl}_{2} ; \mathrm{pH}$ 7.2). The cells were incubated in a glucose-free DMEM base medium and then subjected to hypoxia to mimic the in vivo condition of myocardial ischemia. The cells were placed in an incubator at $37^{\circ} \mathrm{C} . \mathrm{N}_{2}(95 \%)$ and $\mathrm{CO}_{2}(5 \%)$ were flushed into the incubator to bring the oxygen content down to $1 \%$ monitored by an oxygen probe. After $3 \mathrm{~h}$ of hypoxia, the cells were reoxygenated by immediately replacing a glucose-free DMEM base medium with a DMEM base medium with $5.5 \mathrm{mM}$ glucose $(\mathrm{pH} 7.4)$ followed by incubation under normoxia for $2 \mathrm{~h}$.

Experimental groups and protocols. After cardiomyocytes had been cultured for $\sim 72 \mathrm{~h}$, they were in the state of confluence and beat synchronously. The cultured cardiomyocytes were randomly divided into 7 groups: i) control group: cardiomyocytes were incubated under normoxic conditions at $37^{\circ} \mathrm{C}$ during the entire experimental period; ii) hypoxia/ reoxygenation group: cardiomyocytes were incubated with a glucose-free DMEM base medium for $3 \mathrm{~h}$ of hypoxia followed by reoxygenation for $2 \mathrm{~h}$ as described above; iii) picroside II-50 group: picroside II $(50 \mu \mathrm{g} / \mathrm{ml})$ was applied $48 \mathrm{~h}$ prior to hypoxia/reoxygenation; iv) picroside II-100 group: picroside II $(100 \mu \mathrm{g} / \mathrm{ml})$ was applied $48 \mathrm{~h}$ prior to hypoxia/ reoxygenation; v) picroside II $(200 \mu \mathrm{g} / \mathrm{ml})$ group: picroside II (200 $\mu \mathrm{g} / \mathrm{ml}$ ) was applied $48 \mathrm{~h}$ prior to hypoxia/reoxygenation; vi-vii) cells co-treated with hypoxia/reoxygenation and picroside II $(200 \mu \mathrm{g} / \mathrm{ml})$ were challenged with the alternative PI3K inhibitor wortmannin (wortmannin, $50 \mathrm{nM}$ : picroside II + wortmannin group) or 2-(4-morpholinyl)-8-phenyl-4H-1-benzopyran-4-one (LY294002, $15 \mu \mathrm{M}$ : picroside II + LY294002 group).

Cell viability assays. Cell viability was assessed by 3-(4,5-dimethylthiazol-2-yl)-2,5-diphenyl tetrazolium bromide (MTT) assay. The cardiomyocytes were seeded on 96-well plates at $1.2 \times 10^{5}$ cells/well. Following exposure to hypoxiareoxygenation, cardiomyocytes were treated by the addition of $20 \mu \mathrm{l}$ MTT solution ( $5 \mathrm{mg} / \mathrm{ml}$ phosphate buffer) for $4 \mathrm{~h}$ and the media were removed. The formazan blue crystals, formed by oxidation of the MTT dye, were dissolved in $150 \mu \mathrm{l}$ DMSO for $10 \mathrm{~min}$ at the condition of vibration. The absorbance at $490 \mathrm{~nm}$ was measured using a microplate reader (Sunrise RC; Tecan Group, Ltd., Mannedorf, Switzerland) and cell viability was expressed as a percentage of the control culture value.

LDH activity assay. LDH activity was measured as the LDH content was released in the culture medium. After hypoxia/ 


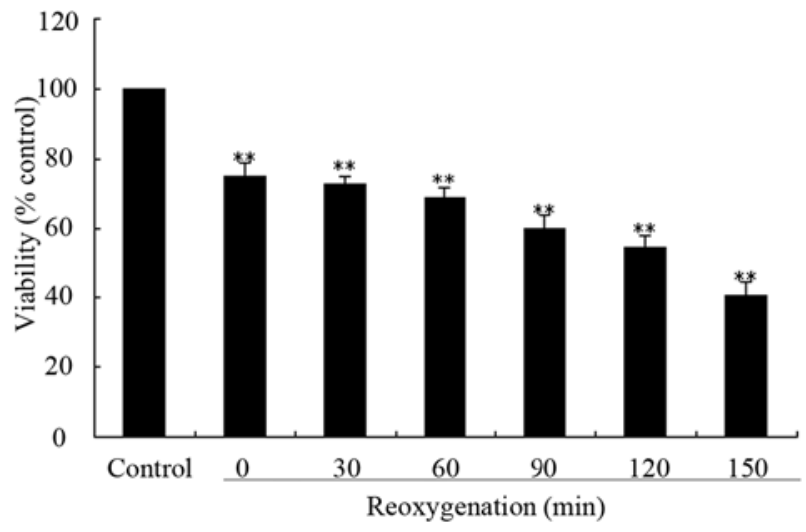

Figure 2. Time-dependent toxic effect of hypoxia/reoxygenation on cardiomyocyte viability. Cardiomyocytes were exposed to hypoxia $3 \mathrm{~h} /$ reoxygenation for 30-150 min. Viable cells were identified with MTT assay data are shown as the mean $\pm \mathrm{SD}$ of 3 experiments; $\mathrm{n}=6 ;{ }^{* *} \mathrm{P}<0.01$ vs. control.

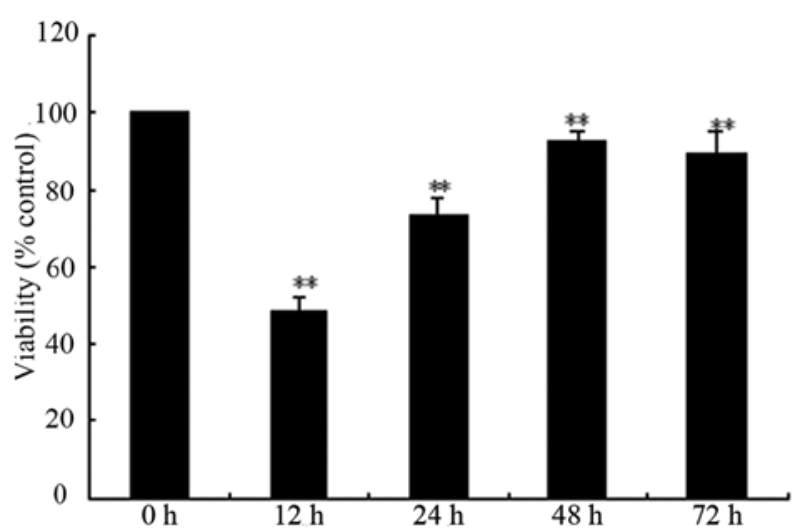

Figure 3. Cardiomyocytes were treated with $200 \mu \mathrm{g} / \mathrm{ml}$ of picroside II for the times indicated. Values are means \pm SD from 5 independent experiments. ${ }^{* *} \mathrm{P}<0.01$ vs. the control group.

reoxygenation, $0.2 \mathrm{ml}$ of culture medium was taken and assayed for LDH activity using commercial kits (Nanjing Jiancheng Bioengineering Institute, Nanjing, China) with a microplate reader (Sunrise RC; Tecan Group, Ltd.), following the manufacturer's instructions.

Caspase-3 activity assay. Caspase-3 activity was measured using the caspase-3 assay kit/colorimetric according to the manufacturer's instructions. Briefly, at the end of hypoxia/ reoxygenation, $2 \times 10^{6}$ cells were collected, centrifuged $1,000 \mathrm{x} \mathrm{g}$ for $10 \mathrm{~min}$ at $4^{\circ} \mathrm{C}$. The cells were resuspended in the lysis buffer, incubated for $5 \mathrm{~min}$ on ice bath and centrifuged at $10,000 \mathrm{x}$ g for $10 \mathrm{~min}$ at $4^{\circ} \mathrm{C}$. The supernatant was then reacted with Ac-DEVD-pNA ( $2 \mathrm{mM})$, which were the substrates of caspase- 3 , at $37^{\circ} \mathrm{C}$ for $2 \mathrm{~h}$. The protein concentration in the supernatant was determined by the BCA method. The absorbance at $405 \mathrm{~nm}$ was measured using a microplate reader (Sunrise RC; Tecan Group, Ltd.).

Nuclear staining for assessment of apoptosis. The nuclei of cardiomyocytes were stained with the chromatin dye Hoechst 33258. Cells were fixed with $4 \%$ paraformaldehyde for $10 \mathrm{~min}$ at room temperature. After three washes with PBS,

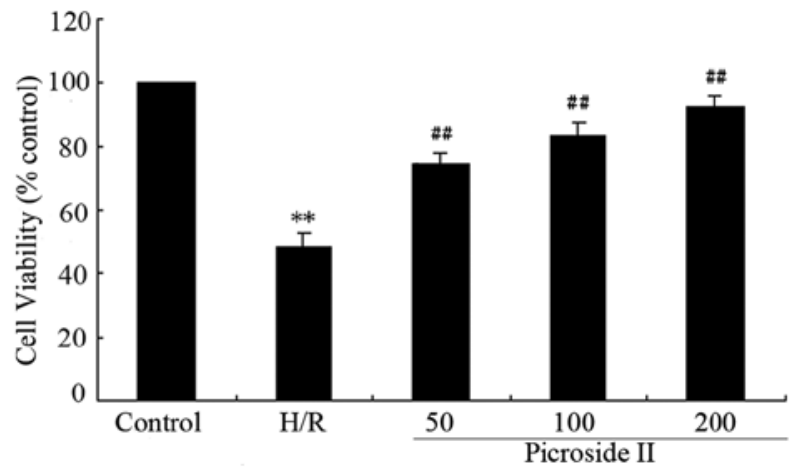

Figure 4. Effects of picroside II $(50,100$ or $200 \mu \mathrm{g} / \mathrm{ml})$ on cell viability in cardiomyocytes subjected to $\mathrm{H} / \mathrm{R}$. Values are expressed as mean $\pm \mathrm{SEM}$; $\mathrm{n}=8 ;{ }^{* *} \mathrm{P}<0.01$ vs. the control group; ${ }^{\# \#} \mathrm{P}<0.01$ vs. the $\mathrm{H} / \mathrm{R}$ group.

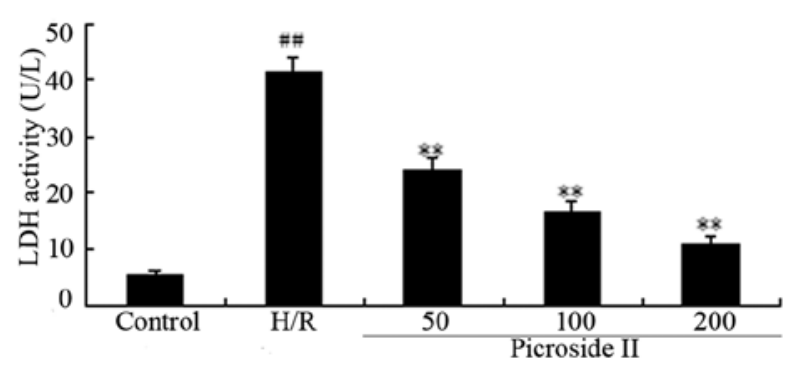

Figure 5. Effects of picroside II $(50,100$ or $200 \mu \mathrm{g} / \mathrm{ml})$ on LDH activity in cardiomyocytes subjected to $\mathrm{H} / \mathrm{R}$. Values are expressed as mean $\pm \mathrm{SEM}$; $\mathrm{n}=8 ;{ }^{\# \#} \mathrm{P}<0.01$ vs. the control group; ${ }^{* *} \mathrm{P}<0.01$ vs. the $\mathrm{H} / \mathrm{R}$ group.

the cells were incubated with Hoechst 33258 (5 $\mu \mathrm{g} / \mathrm{ml}$ in PBS) at room temperature for $15 \mathrm{~min}$. After rinsing with PBS again, the cells were examined under a fluorescence microscope.

Analysis of flow cytometry. The apoptotic cells were measured by Annexin V-FITC/PI staining. At the end of hypoxia/reoxygenation, cells were harvested, washed with PBS, resuspended in binding buffer (10 mM Hepes/ $\mathrm{NaOH} \mathrm{pH} \mathrm{7.4,} 140 \mathrm{mM} \mathrm{NaCl}$ and $2.5 \mathrm{mM} \mathrm{CaCl}_{2}$ ) and incubated with Annexin- $\mathrm{V}$ at room temperature in dark for $15 \mathrm{~min}$. Then the cells were centrifuged, resuspended in the binding buffer and incubated with Propidium iodide (PI). After incubation, $400 \mu 1$ of binding buffer was added and the cells were analyzed by flow cytometry (FACScalibur; BD Biosciences, USA).

Western blot analysis. Cardiomyocytes with various treatments were lysed in an ice-cold RIPA buffer [1\% Triton, $0.1 \%$ SDS, $0.5 \%$ deoxycholate, $1 \mathrm{mmol} / 1$ EDTA, $20 \mathrm{mmol} / 1$ Tris (pH 7.4), $150 \mathrm{mmol} / \mathrm{l} \mathrm{NaCl}, 10 \mathrm{mmol} / \mathrm{NaF}$ and $0.1 \mathrm{mmol} / \mathrm{l}$ phenylmethylsulfonyl fluoride (PMSF)]. The lysates were centrifuged at $12,000 \mathrm{rpm}$ for $15 \mathrm{~min}$ at $4^{\circ} \mathrm{C}$ to remove debris. The protein concentration was determined with BCA protein assay. Equal amounts of denatured protein samples (50-100 $\mu \mathrm{g}$ protein/lane) were separated by $10-12 \%$ sodium dodecyl sulfate-polyacrylamide gelelectrophoresis (SDS-PAGE) and transferred to polyvinylidene difluoride (PVDF) membranes. Membranes were then washed with TTBS 3 times and incubated further with horseradish peroxidase-conjugated secondary antibody $(1: 2,000)$ for $2 \mathrm{~h}$ at room temperature. 

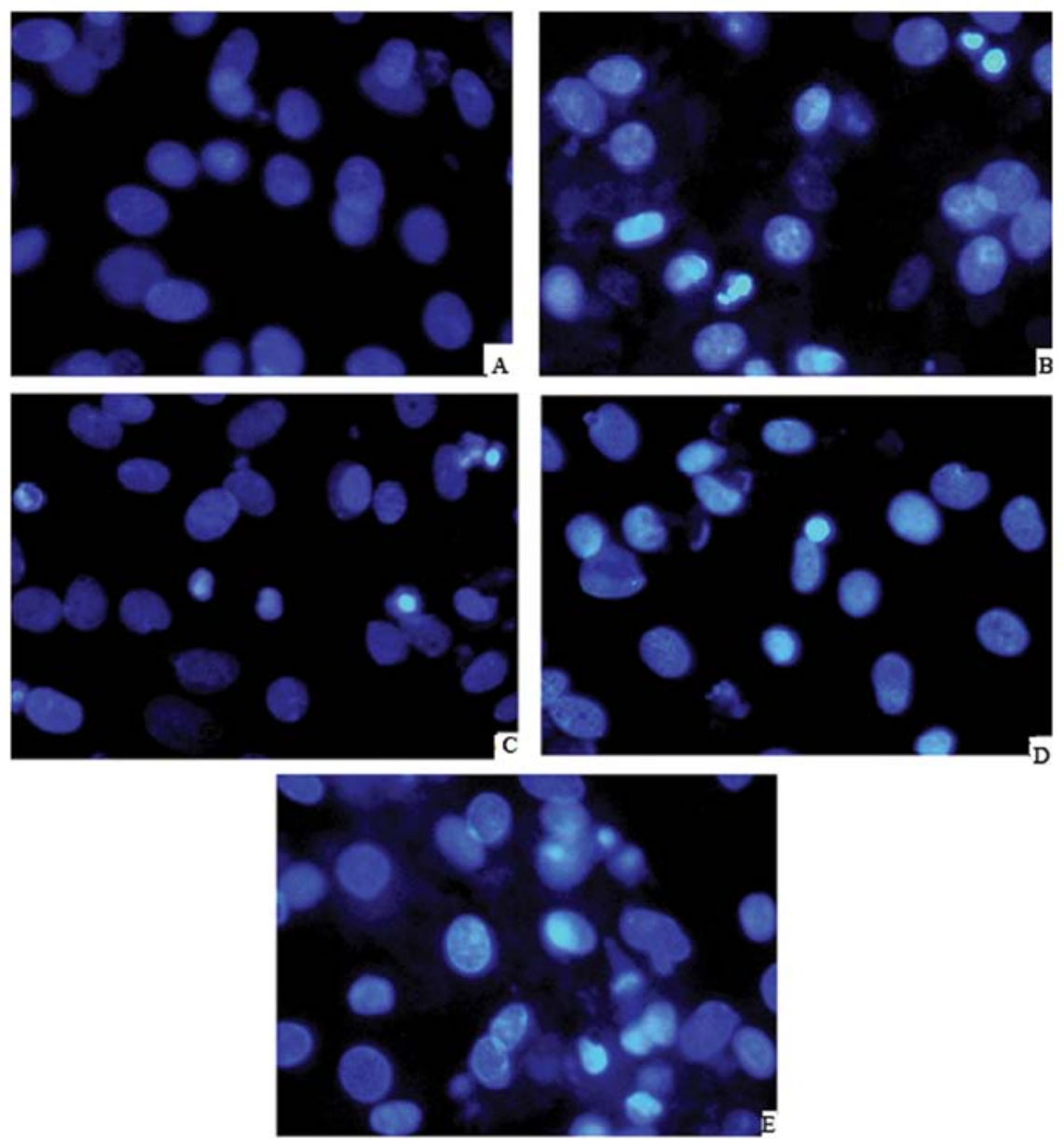

Figure 6. Effect of picroside II on histochemical characterization of hypoxia-induced apoptotic myocytes (magnification, x400). (A) Control; (B) hypoxia/ reoxygenation; (C) hypoxia/reoxygenation + picroside II (200 $\mu \mathrm{g} / \mathrm{ml})$ group; (D) hypoxia/reoxygenation + picroside II $(200 \mu \mathrm{g} / \mathrm{ml})+\mathrm{LY} 294002(10 \mu \mathrm{M})$ group (co-pretreatment of cells with LY294002 for $1 \mathrm{~h})$; (E) hypoxia/reoxygenation + picroside II ( $200 \mu \mathrm{g} / \mathrm{ml})+$ wortmannin $(50 \mathrm{nM})$ group (co-pretreatment of cells with wortmannin for $1 \mathrm{~h}$ ).

The blots were processed using an electrochemiluminescence (ECL) kit and and light emission was captured on X-ray film. The blots were visualized with ECL-plus reagent and then subjected to densitometric analysis. $\beta$-actin was used as the internal loading control.

Statistical analysis. The data are expressed as the mean $\pm \mathrm{SD}$. One-way analysis of variance (ANOVA) followed by the Student-Newman-Keuls test. Differences were considered to be statistically significant at $\mathrm{P}<0.05$.

\section{Results}

Effect of picroside II on the viability of cardiomyocytes subjected to hypoxia/reoxygenation. The results show that pre-incubation of cardiomyocytes with different concentrations of picroside II $(0,6.25,12.5,25,50,100,200,400$ and $800 \mu \mathrm{g} / \mathrm{ml}$ ) prevented the loss of viability that resulted from hypoxia/reoxygenation in a dose-dependent manner (data not shown). Maximum viability was apparent at a concentration of $200 \mu \mathrm{g} / \mathrm{ml}$. However, higher concentrations (400 and $800 \mu \mathrm{g} / \mathrm{ml}$ ) of picroside II did not cause any enhancement of this preventive effect. We analyzed the effective half-maximal concentration for protection (EC50) was $50 \mu \mathrm{g} / \mathrm{ml}$. Therefore, we used concentrations of picroside II $(50,100$ or $200 \mu \mathrm{g} / \mathrm{ml})$ for our subsequent experiments. As shown in Fig. 2, hypoxia $3 \mathrm{~h}$ /reoxygenation for 30-150 min significantly decreased the percentage of survival cells in a time-dependent manner. Subjected to hypoxia $3 \mathrm{~h} /$ reoxygenation for $120 \mathrm{~min}$, there were only $54.29 \pm 3.4 \%$ viable cells as compared to the control cells. Thus, hypoxia $3 \mathrm{~h} /$ reoxygenation $120 \mathrm{~min}$ was used as a standard apoptosis induction in the subsequent experiments.

Fig. 3 shows the results of the time-response investigation during which cells were exposed to $200 \mu \mathrm{g} / \mathrm{ml}$ picroside II for $\leq 72 \mathrm{~h}$. The magnitude of cell survival peaked at $48 \mathrm{~h}$, when cell viability was $92.3 \pm 3.02 \%$. Fig. 4 shows that after exposure to hypoxia $3 \mathrm{~h} /$ reoxygenation for $2 \mathrm{~h}$ the survival rate of cardiomyocytes was $48.25 \pm 4.31 \%$. Pre-incubation with picroside II $(50,100$ and $200 \mu \mathrm{g} / \mathrm{ml})$ prevented cardiomyocytes from hypoxia/reoxygenation-induced damage, and caused a dose-dependent attenuation in cell survival to $74.17 \pm 3.51$, $83 \pm 4.5$ and $92.02 \pm 3.6 \%$, respectively (all $\mathrm{P}<0.01$ vs. hypoxia/ reoxygenation).

Effect of picroside II on the levels of LDH in cardiomyocytes subjected to hypoxia/reoxygenation. The release of LDH in the medium is widely known as an indicator of cardiomyocyte injury. As shown in Fig. 5, LDH concentrations in medium 

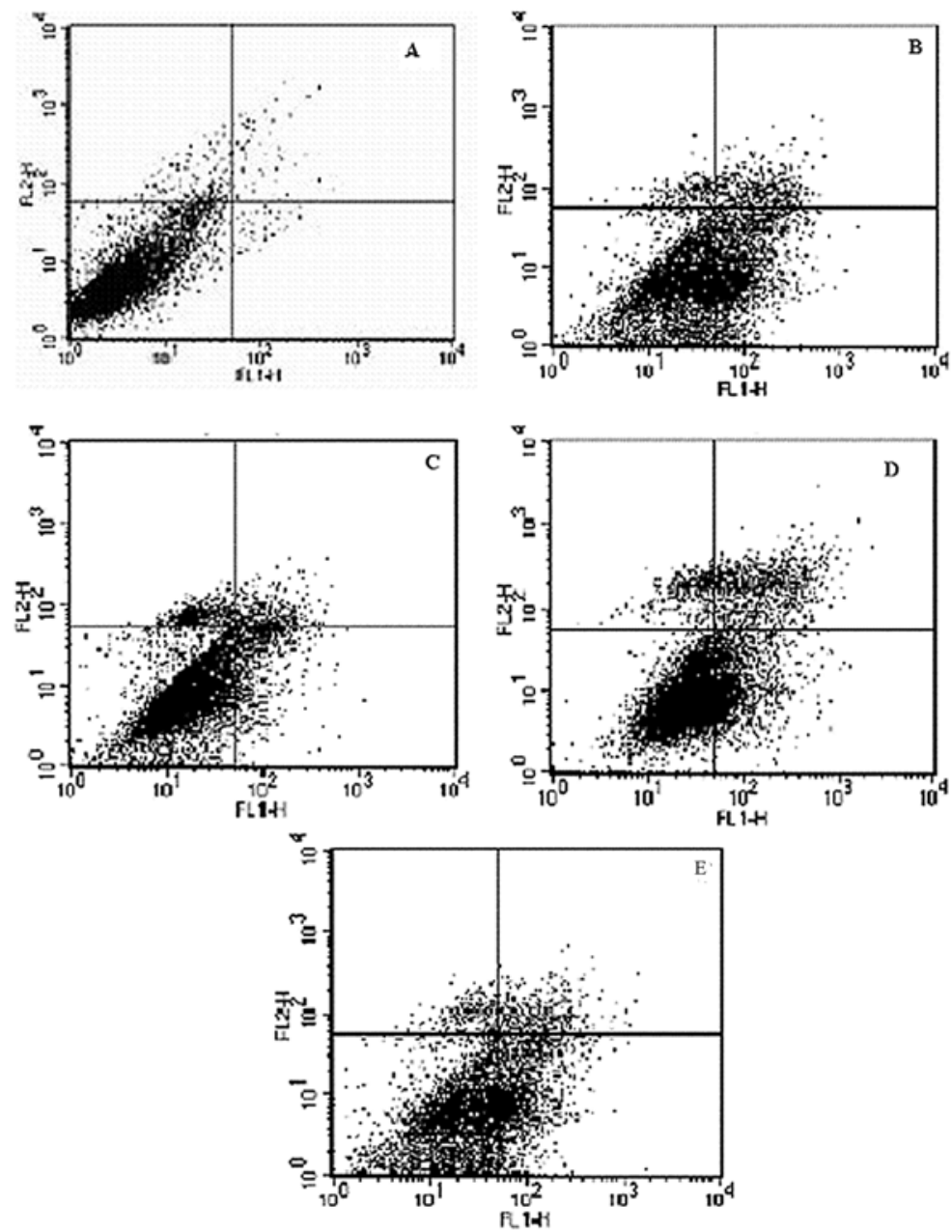

Figure 7. Effect of picroside II on hypoxia/reoxygenation-induced cardiomyocyte necrosis and apoptosis was determined with flow cytometry. (A) Control; (B) hypoxia/reoxygenation; (C) hypoxia/reoxygenation + picroside II (200 $\mu \mathrm{g} / \mathrm{ml})$ group; (D) hypoxia/reoxygenation + picroside II (200 $\mu \mathrm{g} / \mathrm{ml})+\mathrm{LY} 294002$ $(10 \mu \mathrm{M})$ group; (E) hypoxia/reoxygenation + picroside II $(200 \mu \mathrm{g} / \mathrm{ml})+$ wortmannin $(50 \mathrm{nM})$ group.

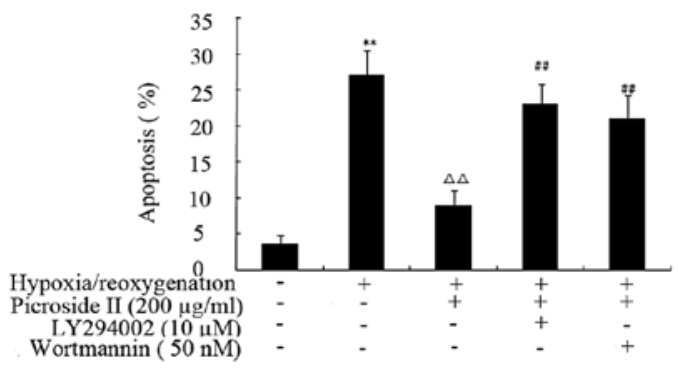

Figure 8 . The percentage of apoptosis in cardiomyocytes from the control or the pretreated groups. All data were expressed as mean $\pm \mathrm{SD} ; \mathrm{n}=6 ;{ }^{* *} \mathrm{P}<0.01$ vs. control, $\Delta \Delta \mathrm{P}<0.01$ vs. hypoxia/reoxygenation; ${ }^{\# \#} \mathrm{P}<0.01$ vs. the hypoxia/ reoxygenation + picroside II group.

from control group cells were minimal $(5.63 \pm 0.39 \mathrm{U} / \mathrm{l})$, while LDH activity induced by hypoxia/reoxygenation increased up to $(41.5 \pm 2.71 \mathrm{U} / \mathrm{l})$. Treatment with picroside II $(50,100$ and $200 \mu \mathrm{g} / \mathrm{ml}$ ) significantly attenuated LDH activity in a dose-dependent manner (concentrations were $24.02 \pm 2.0 \mathrm{U} / 1$, $16.69 \pm 1.92 \mathrm{U} / 1$ and $10.09 \pm 1.38 \mathrm{U} / 1$, respectively).

Effect of picroside II on apoptosis in cardiomyocytes subjected to hypoxia/reoxygenation. Hoechest 33258 staining assay

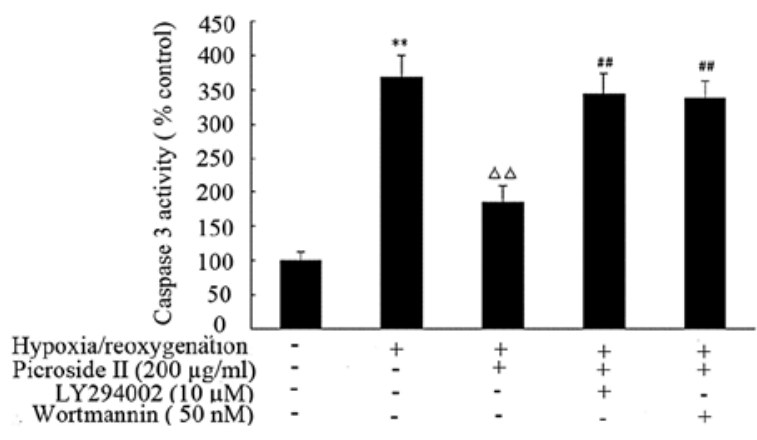

Figure 9. Inhibitory effect of picroside II on hypoxia/reoxygenation induced caspase- 3 activity . Cells were pretreated with $200 \mu \mathrm{g} / \mathrm{ml}$ picroside II for $48 \mathrm{~h}$ and then exposed to hypoxia $3 \mathrm{~h} /$ reoxygenation $2 \mathrm{~h}$. Protection of picroside II was abrogated by the PI3K inhibitor LY294002 or wortmannin treatment. Caspase-3 activity was determined as described in the Materials and methods $(\mathrm{n}=6)$. Data are presented as the mean $\pm \mathrm{SD} ; \mathrm{n}=6 ;{ }^{* * *} \mathrm{P}<0.01$ vs. control, $\Delta \Delta \mathrm{P}<0.01$ vs. hypoxia/reoxygenation; ${ }^{\# \#} \mathrm{P}<0.01$ vs. the hypoxia/ reoxygenation + picroside II group.

showed that cardiomyocytes exposed to hypoxia/reoxygenation featured typical characteristics of apoptosis, including the condensed chromatin and the fragmented apoptotic nuclei. However, the development of these apoptotic features were 


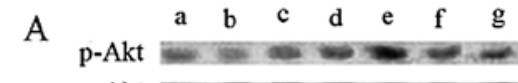

Akt
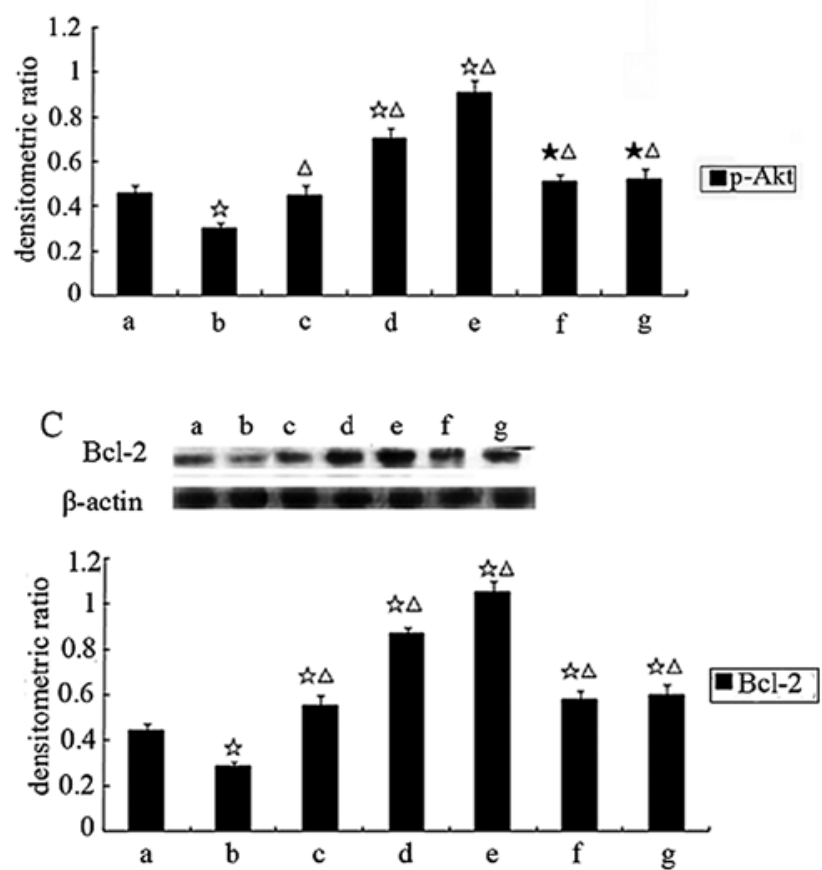

B
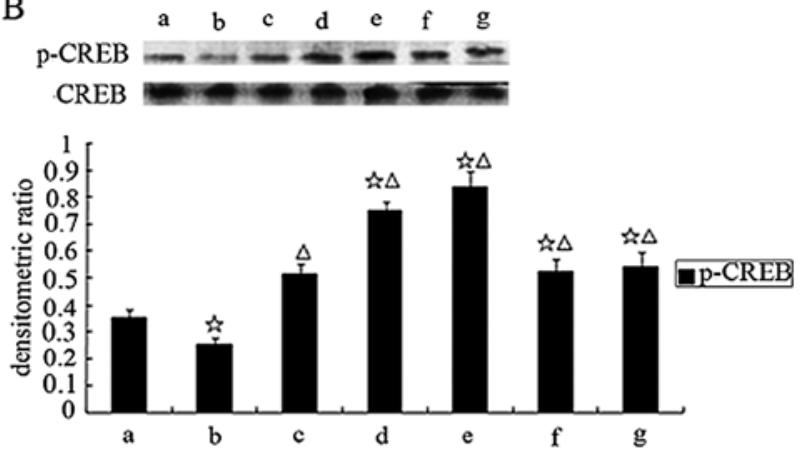

$\mathrm{D}$
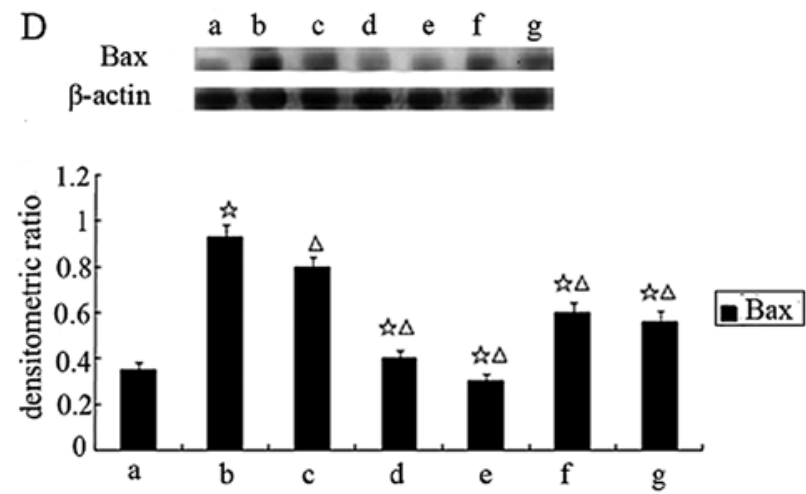

Figure 10. Representative western blot analysis showing the protein expression. (A) Phosphorylated Akt and total Akt; (B) phosphorylated CREB and total CREB; (C) Bcl-2; (D) Bax. a, control group; b, hypoxia/reoxygenation; c, $50 \mu \mathrm{g} / \mathrm{ml}$ picroside II group; d, $100 \mu \mathrm{g} / \mathrm{ml}$ picroside II group; e, $200 \mu \mathrm{g} / \mathrm{ml}$ picroside II group; f, picroside II + LY294002 group; g, picroside II + wortmannin group. Data were expressed as densitometric ratio. Values are mean \pm SD; $=3 ;{ }^{\star} \mathrm{P}<0.05$ and ${ }^{\wedge} \mathrm{P}<0.01$ vs. the control group; ${ }^{\circ} \mathrm{P}<0.01$ vs. hypoxia/reoxygenation.

significantly suppressed when cells were treated with picroside II (200 $\mu \mathrm{g} / \mathrm{ml})$ (Fig. 6).

Flow cytometry revealed that hypoxia-reoxygenation caused a significant increase in the percentage of apoptotic cells from $3.3 \pm 0.95 \%$ in control cells to $27.09 \pm 3.42 \%(\mathrm{P}<0.01)$ (Fig. 7). However, when picroside II $(200 \mu \mathrm{g} / \mathrm{ml})$ was applied $48 \mathrm{~h}$ prior to hypoxia-reoxygenation, it caused a reduction in the percentage of apoptotic cells to $9.05 \pm 2.0 \%(\mathrm{P}<0.01)$ (Fig. 8).

Cardiomyocytes exposed to hypoxia/reoygenation insults had an increase in caspase-3 activation $(368.3 \pm 32.12)$ comparing to the control group $(100 \pm 12.01)$. Treatment with picroside II $(200 \mu \mathrm{g} / \mathrm{ml})$ for $48 \mathrm{~h}$ significantly decreased this hypoxia/reoygenation-induced caspase-3 activation (Fig. 9).

However, the protection of picroside II was partially blocked by pretreating cells with wortmannin or LY294002. These results provide direct evidence that picroside II can significantly inhibit apoptosis in cardiomyocytes induced by hypoxia/reoygenation, and that this effect is partially inhibited by concurrent wortmannin or LY294002 treatment.

Effect of picroside II on the phosphorylation of Akt and $C R E B$ in cardiomyocytes exposed to hypoxia/reoxygenation. The kinetics of Akt activation were examined, to evaluate a possible mechanism for the anti-apoptotic effect of picroside II. As shown in Fig. 10A, hypoxia/reoxygenation significantly reduced the phosphorylation of Akt without alteration of the total Akt expression. Pretreatment of cardiomyocytes with picroside II, prior to hypoxia/reoxygenation exposure, resulted in a significant increase in the phosphorylation of Akt. In addition, CREB, a downstream target of Akt, was also markedly phosphorylated (Fig. 10B). Both $50 \mathrm{nM}$ wortmannin and $15 \mu \mathrm{M}$ LY294002 markedly inhibited picroside II-induced Akt and CREB phosphorylation.

Effect of picroside II on the phosphorylation of Bcl-2 and Bax in cardiomyocytes exposed to hypoxia/reoxygenation. Akt phosphorylates the transcription factor CREB, implicated in the transcription of the anti-apoptotic Bcl-2 gene (17). We investigated the protein expression of the anti-apoptotic Bcl-2 and the pro-apoptotic Bax. As shown in Fig. 10C, the expression of Bcl-2 protein decreased in the hypoxia/reoxygenation group compared to the control group. However, cells treated with picroside II showed an increase in Bcl-2 protein expression as detected by western blot analysis. Picroside II pretreatment downregulated Bax levels in cells exposed to hypoxia/reoxygenation comparing to untreated cells (Fig. 10D). This effect was partially inhibited by concurrent wortmannin or LY294002 treatment. Picroside II treatment mediated phosphorylation of Akt and CREB, increased Bcl-2 protein expression, and decreased Bax protein expression and caspase-3 activity in cardiomyocytes hypoxia/reoxygenation, which was abolished by LY294002 or wortmannin treatment.

\section{Discussion}

Through examination, we firstly proved the cardioprotective effects of picroside II on apoptosis induced by hypoxia/ reoxygenation in a neonatal rat cardiomyocyte. In the present study, we demonstrated that pretreatment of cardiomyocytes with picroside II $(50-200 \mu \mathrm{g} / \mathrm{ml})$ for $48 \mathrm{~h}$ significantly reduced 
the decrease in viability and LDH activities associated with exposure to hypoxia/reoxygenation as determined by MTT and LDH assays. Picroside II decreased hypoxia/reoxygenation-induced apoptosis in cardiomyocytes as indicated by nuclear morphological Hoechst staining, flow cytometry and caspase-3 activity. These results indicate that picroside II protects against hypoxia/reoxygenation-induced apoptosis in that it not only involves enhanced phosphorylation of Akt and CREB, but also upregulation of Bcl-2 and downregulation of Bax via the PI3-kinase/Akt signaling pathway.

Picroside II is a major iridoid glucoside isolated from Picrorhiza scrophulariiflora Pennell (Scrophulariaceae) (3). Previous studies have shown that picroside II has a number of pharmacological effects, including neuroprotective $(4,5)$, hepatoprotective (6), antioxidant, anticholestatic, anti-inflammatory and immunemodulating activities $(7,8)$. In addition, picroside II is also reported to possess potent anti-apoptotic activities $(5,6)$. It has been reported to stimulate anti-apoptotic proteins such as Bcl-2 (6) and inhibit proteins with pro-apoptotic properties such as caspase-3 and poly ADP-ribose polymerase (PARP) (5). The most demonstrated findings are from studies in neuronal cells $(4,5)$. In the present study, we examined the effect of picroside II on the viability of cardiomyocytes subjected to hypoxia/ reoxygenation by MTT and LDH assays. Apoptosis was also assessed by Hoechst 33258 staining, Annexin V-FITC staining and caspase- 3 activity. We found that picroside II protected cardiomyocytes from hypoxia/reoxygenation-induced decrease in cell viability and apoptosis.

The mechanism by which picroside II protects cardiomyocytes from hypoxia/reoxygenation-induced apoptosis is an important issue raised by the results presented in this study. Multiple signaling pathways participate in regulation of cell survival. Our study emphasized on examining potential changes in the Akt-CREB pathway. Akt is a critical regulator of PI3-kinase-mediated cell proliferation and survival (18). Akt is involved in many cell anabolic processes, including glucose transport, glycogen synthesis, and protein synthesis (19). Akt can also regulate the process of cell survival through phosphorylation of diverse target molecules including the Bcl-2-family member Bad, Forkhead, caspase-9, NF- $\mathrm{KB}$ and CREB $(20,21)$.

Akt also activates cAMP response element binding (CREB) protein, stimulates recruitment of CBP to the promoter and promotes cellular survival through a CRE-dependent mechanism $(22,23)$. The transcription factor CREB mediates survival in many cells, including cardiomyocytes. It has been shown that Bcl-2 is one of the most important CREB-regulated genes, playing a critical role in the cell survival (24). The promoter region of Bcl-2 contains a cAMP-response element site and CREB is known as a positive regulator of Bcl-2 expression (25-27). Furthermore, activated CREB can also inhibit caspase- 3 activation and finally attenuate myocyte apoptosis (28). In line with this notion, our results showed that picroside II upregulated Bcl-2 protein expression and inhibited caspase-3 activation in the hypoxia/reoxygenation myocytes, which was accompanied by a significant increase of CREB phosphorylation. In this study, we found that Akt predominantly existed in an inactivated form in cardiomyocytes that were not undergoing hypoxia/reoxygenation, but was activated and phosphorylated when cells were co-treated with hypoxia/reoxygenation and picroside II. Picroside II markedly increased the phosphory- lation of Akt and CREB. This activation was significantly blocked by the PI3K inhibitor wortmannin and LY294002. These results suggest that picroside II may protect cardiomyocytes from hypoxia/reoxygenation-induced apoptosis at least in part by activating the PI3K/Akt-CREB signaling pathway.

Many genes have been reported to be involved in the regulation of apoptosis, in which Bcl-2 and Bax genes are suggested to play a major role in maintaining the balance of cell death and survival $(29,30)$. The main site of action of Bcl-2 family proteins appears to be the mitochondrion. Several studies have shown that the anti-apoptotic protein $\mathrm{Bcl}-2$ and the proapoptotic protein Bax of the Bcl-2 family are associated with the mitochondrial membrane and affect membrane permeability (31). Bcl-2 prevent the release of cytochrome $\mathrm{c}$ from the mitochondria by binding to the pro-apoptotic proteins Bad, Bax and Bak $(32,33)$. Thus, it can inhibit activation of caspases, such as caspase-9 and caspase-3, and prevent apoptosis $(34,35)$. Moreover, it has been shown that upregulation of Bcl-2 can antagonize the pro-apoptotic activities of Bax and Bak (36). To further support our findings, the effects of picroside II on expression of $\mathrm{Bcl}-2$ and Bax proteins were detected by western blot analysis. In the present study, we found that hypoxia/ reoxygenation downregulated the expression of Bcl-2, whereas upregulated Bax expression. Pretreatment with picroside II ameliorated these changes in Bax and Bcl-2 protein expression. Furthermore, these effects were partially abolished by the PI3K inhibitor wortmannin and LY294002. Our findings suggest that Bcl-2 and Bax are involved in mediating the anti-apoptotic effects associated with picroside II treatment in cardiomyocytes exposed to hypoxia/reoxygenation.

In conclusion, our study for the first time demonstrates, that picroside II protects cardiomyocytes from hypoxia/reoxygenationinduced apoptosis. Our results also suggest that the anti-apoptotic effects associated with picroside II pretreatment are at least in part due to inhibited caspase-3 activation, activation of the PI3K/Akt/ CREB signaling pathway and modulated Bcl-2 and Bax expression. Picroside II may hold promise as a therapeutic intervention for the treatment of myocardial ischemia/reperfusion. Further detailed investigation is needed in these fields.

\section{References}

1. Bennett MR: Apoptosis in the cardiovascular system. Heart 87: 480-487, 2002.

2. Kang PM and Izumo S: Apoptosis in heart: basic mechanisms and implications in cardiovascular diseases. Trends Mol Med 9: 177-182, 2003.

3. Li P, Matsunaga K, Yamakuni T and Ohizumi Y: Potentiation of nerve growth factor- action by picrosides I and II, natural iridoids, in PC12D cells. Eur J Pharmacol 406: 203-208, 2000.

4. Li T, Liu JW, Zhang XD, Guo MC and Ji G: The neuroprotective effect of picroside II from hu-huang-lian against oxidative stress. Am J Chin Med 35: 681-691, 2007.

5. Li Q, Li Z, Xu XY, Guo YL and Du F: Neuroprotective properties of picroside II in a rat model of focal cerebral ischemia. Int $J$ Mol Sci 11: 4580-4590, 2010.

6. Gao H and Zhou YW: Inhibitory effect of picroside II on hepatocyte apoptosis. Acta Pharmacol Sin 26: 729-736, 2005.

7. Cao Y, Liu JW, Yu YJ, Zheng PY, Zhang XD, Li T and Guo MC: Synergistic protective effect of picroside II and NGF on PC12 cells against oxidative stress induced by $\mathrm{H}_{2} \mathrm{O}_{2}$. Pharmacol Rep 59: 573-579, 2007.

8. Smit HF, Kroes $\mathrm{BH}$, van den Berg AJ, van der Wal D, van den Worm E, BeukelmanCJ, van Dijk H and Labadie RP: Immunomodulatory and anti-inflammatory activity of Picrorhiza scrophulariiflora. J Ethnopharmacol 73: 101-109, 2000. 
9. He LJ, Liang M, Hou FF, Guo ZJ, Xie D and Zhang X: Ethanol extraction of Picrorhiza scrophulariiflora prevents renal injury in experimental diabetes via anti-inflammation action. J Endocrinol 200: 347-355, 2009

10. Hers I, Vincent EE and Tavaré JM: Akt signalling in health and disease. Cellular Signal 23: 1515-1527, 2011.

11. Kvansakul M, Yang H, Fairlie WD, Czabotar PE, Fischer SF, Perugini MA, Huang DC and Colman PM: Vaccinia virus antiapoptotic F1L is a novel Bcl-2-like domain-swapped dimer that binds a highly selective subset of $\mathrm{BH} 3$-containing death ligands. Cell Death Differ 15: 1564-1571, 2008.

12. Youle RJ and Strasser A: The Bcl-2 protein family: opposing activities that mediate cell death. Nat Rev Mol Cell Biol 9: 47-59, 2008

13. Estaquier $\mathbf{J}$ and Arnoult D: Inhibiting Drp1-mediated mitochondrial fission selectively prevents the release of cytochrome c during apoptosis. Cell Death Differ 14: 1086-1094, 2007.

14. Cory S, Huang DC and Adams JM: The Bcl-2 family: roles in cell survival and oncogenesis. Oncogene 22: 8590-8607, 2003.

15. Reinecke H, Zhang M,Bartosek T and Murry CE: Survival, integration, and differentiation of cardiomyocyte grafts: A study in normal and injured rat hearts. Circulation 100: 193-202, 1999.

16. Zhu D, Wu L, Li CR, Wang XW, Ma YJ, Zhong ZY, Zhao HB, Cui J, Xun SF, Huang XL, et al: Ginsenoside Rg1 protects rat cardiomyocyte from hypoxia/reoxygenation oxidative injury via antioxidant and intracellular calcium homeostasis. J Cell Biochem 108: 117-124, 2009.

17. Willaime-Morawek S, Arbez N, Mariani J and Brugg B: IGF-I protects cortical neurons against ceramide-induced apoptosis via activation of the PI-3K/Akt and ERK pathways; is this protection independent of CREB and Bcl-2? Mol Brain Res 142: 97-106, 2005.

18. Wang B, Shravah J, Luo H, Raedschelders K, Chen DD and Ansley DM: Propofol protects against hydrogen peroxideinduced injury in cardiac $\mathrm{H} 9 \mathrm{c} 2$ cells via Akt activation and $\mathrm{Bcl}-2$ up-regulation. Biochem Biophys Res Commun 389: 105-111, 2009.

19. Nathan KL, Kenneth W and Zoltan A: Metabolic benefits of resistance training and fast glycolytic skeletal muscle. Am J Physiol Endocrinol Metab 300: E3-E10, 2011.

20. Matsui $\mathrm{T}$ and Rosenzweig A: Convergent signal transduction pathways controlling cardiomyocyte survival and function: the role of PI3-kinase and Akt. J Mol Cell Cardiol 38: 63-71, 2005.

21. Gao F, Gao E, Yue TL, Ohlstein EH, Lopez BL, Christopher TA and Ma XL: Nitric oxide mediates the antiapoptotic effect of insulin in myocardial ischemia reperfusion: the roles of PI3-kinase, Akt, and endothelial nitric oxide synthase phosphorylation. Circulation 105: 1497-1502, 2002.

22. Du K and Montminy M: CREB is a regulatory target for the protein kinase Akt/PKB. J Biol Chem 273: 32377-32379, 1998.
23. Dudek H, Datta SR, Franke TF, Birnbaum MJ, Yao R, Cooper GM, Segal RA, Kaplan DR and Greenberg ME: Regulation of neuronal survival by the serine-threonine protein kinase Akt. Science 275: 661-665, 1997.

24. Walton MR and Dragunow I: Is CREB a key to neuronal survival? Trends Neurosci 23: 48-53, 2000.

25. Pugazhenthi S, Nesterova A, Sable C, Heidenreich KA, Boxer LM, Heasley LE and Reusch JE: Akt/protein kinase B up-regulates Bcl-2 expression through cAMP-response elementbinding protein. J Biol Chem 275: 10761-10766, 2000.

26. Freeland K, Boxer LM and Latchman DS: The cyclic AMP response element in the $\mathrm{Bcl}-2$ promoter confers inducibility by hypoxia in neuronal cells. Brain Res Mol Brain Res 92: 98-106, 2001.

27. Meller R, Minami M, Cameron JA, Impey S, Chen D, Lan JQ, Henshall DC and Simon RP: CREB-mediated Bcl-2 protein expression after ischemic preconditioning. J Cereb Blood Flow Metab 2: 234-246, 2005.

28. Tokudome T, Horio T, Fukunaga M, Okumura H, Hino J, Mori K, Yoshihara F, Suga S, Kawano Y, Kohno M and Kangawa K: Ventricular nonmyocytes inhibit doxorubicin-induced myocyte apoptosis: involvement of endogenous endothelin-1 as a paracrine factor. Endocrinology 145: 2458-2466, 2004.

29. Reed JC: Double identity for proteins of the Bcl-2 family. Nature 387: 773-776, 1997.

30. Liu S, Pereira NA, Teo JJ, Miller P, Shah P and Song Z: Mitochondrially targeted Bcl-2 and Bcl-X(L) chimeras elicit different apoptotic responses. Mol Cells 24: 378-387, 2007.

31. Tanner EA, Blute TA, Brachmann CB and McCall K: Bcl-2 proteins and autophagy regulate mitochondrial dynamics during programmed cell death in the Drosophila ovary. Development 138: 327-338, 2011.

32. Parone PA, James DI, Cruz SD, Mattenberger Y, Donzé O, Barja $\mathrm{F}$ and Martinou JC: Inhibiting the mitochondrial fission machinery does not prevent Bax/Bak-dependent apoptosis. Mol Cell Biol 26: 7397-7408, 2006.

33. Chong ZZ,Kang JQ and Maiese K: Apaf-1, Bcl-xL, Cytochrome c, and caspase- 9 form the critical elements for cerebral vascular protection by erythropoietin. J Cereb Blood Flow Metab 23: 320-330, 2003.

34. Solange D and Martinou JC: Mitochondria as the central control point of apoptosis. Trends Cell Biol 10: 369-377, 2000.

35. Lamothe B and Aggarwal BB: Ectopic expression of Bcl-2 and Bcl-xL inhibits apoptosis induced by TNF-related apoptosisinducing ligand (TRAIL) through suppression of caspases-8, 7, and 3 and BID cleavage in human acute myelogenous leukemia cell line HL-60. J Interferon Cytokine Res 22: 269-279, 2002.

36. Giam M, Huang DC and Bouillet P: BH3-only proteins and their roles in programmed cell death. Oncogene 27: S128-S136, 2008. 